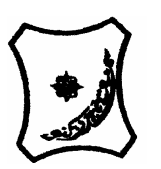

Bayero Journal of Pure and Applied Sciences, 2(2): 116 - 120

Received: May, 2009

Accepted: November, 2009

\title{
AN ANALYSIS OF URBAN IRRIGATION FARMING AND ITS URBAN PLANNING IMPLICATION: CASE STUDY OF KATSINA URBAN AREA, NIGERIA
}

\author{
Murtala Mohammed Ruma \\ Department of Geography, Umaru Musa Yar'adua University, PMB 2218 Katsina, Nigeria \\ Email: mmruma@gmail.com
}

\begin{abstract}
This paper examines the status of wastewater reuse in urban farming in Katsina, an important urban area in the semi arid region of Nigeria. A total of 130 households were selected and interviewed out of the total number of 276 that officially registered with the Katsina Urban Planning Authority. It was found that the reuse of wastewater in urban farming in the area is not only practised as a fulltime and sole income earner for many households, but an activity that the town cannot do without. Appropriate recommendation on how to promote the activity and get it integrated into planning processes in the area have been given.
\end{abstract}

Key word: Urban, Agriculture, Farming, Semi-Arid, Nigeria,

\section{INTRODUCTION}

Production of food in the city has a long history, both in the developed (in the form of allotment gardens) and developing world. The traditional view of food production is that it is essentially a business of rural areas. In many developing areas however, non-built up urban lands, especially those lying along the courses of urban drainage systems, are sometimes seen as locations for the production of some agricultural products that are in high demand by urban dwellers (such as vegetables). Several research workers have shown that a significant proportion of a city's food requirements in developing countries are supplied from within the urban boundaries, because within those areas substantial amount of wastewater (mainly from homes and industries) is available in urban drains for irrigating lands along the urban drainage courses. According to Mbiba and Van Veenhuizen, (2001), in the early 1990s, there has been increasing recognition amongst the scientific and development community of the rising importance of wastewater-based food production in city areas, particularly in those parts of the world that have been characterised by economic collapse. In cities of many arid and semi-arid areas, this is sometimes the only major source of irrigating urban lands being used for food production and fortunately for such areas, there are no prohibitions of disposal of wastewater in urban rivers. Wastewater disposal in rivers has several benefits including maintaining adequate environmental flows and boosting the water volume for downstream users. Treated effluent can be used for irrigation under controlled conditions to minimise health risks arising from pathogenic and toxic pollution of the agricultural produce, soils, surface and ground water.

The growing demand of water for irrigation has produced a marked increase in the reuse of treated and/or untreated wastewater worldwide. The use of industrial or municipal wastewater in agriculture is a common practice in many parts of the world (Urie 1986; Feigin et al. 1991; Blumenthal et al. 2000; Ensink et al. 2002; WHO 2006; Sharma et al. 2007). Rough estimates indicate that at least 20 million hectares in 50 countries are irrigated with raw or partially treated wastewater (Scott et al. 2004; Hussain et al. 2001). The major objectives of wastewater irrigation are that it provides a reliable source of water supply to farmers and has the beneficial aspects of adding valuable plant nutrients and organic matter to soil (Liu et al. 2005b; Horswell et al. 2003). With careful planning and management, the positive aspects of wastewater irrigation can be achieved (WHO 2006).

Urban and peri-urban agriculture (UPA) can offer wide-ranging benefits (Pasquini, 2006). It can contribute substantial amounts to the proportion of food consumed in the city. Sweet (1999), for example, has estimated that $15-20 \%$ of the world's supply of vegetables and meat is produced in urban areas, and FAO (1999) estimates that 800 million urban dwellers are actively engaged in UPA, 200 million providing food for markets (FAO, 1999). UPA is practiced for a variety of reasons, for crisis management when markets are not working (e.g. in Cuba), as a strategy to overcome cash shortages or even for commercial purposes. As well as improving food security and nutrition, and creating employment for the jobless (Lynch et al., 2001), UPA can offer a range of environmental benefits, including improved waste recycling, and additional health benefits such as improved physical and psychological health due to increased physical activity (Lock and van Veenhuizen, 2001). The objective of this paper is to contribute to this body of knowledge by examining the nature, determinants and problems of waste water reuse in urban farming in Katsina, an important urban area in semi-arid region of Nigeria. 
UNDP (1996) defines urban agriculture as an industry that produces processes and markets food and fuel, largely in response to daily demand of consumers within a town, city or metropolis, on land and water dispersed throughout the urban and peri-urban area. It applies intensive production methods, using and recycling into five broadly defined farming systems: aquaculture, horticulture, animal husbandry, agroforestry and other urban farming activities. The focus of this paper is on urban irrigation farming.

\section{Study Area}

Katsina urban area, located at the extreme northern margin of Nigeria, covers a total land area of about 3,370 square kilometers and lies between latitudes $11^{\circ} 08^{\prime} \mathrm{N}$ and $13^{\circ} 22^{\prime} \mathrm{N}$ and longitude $6^{\circ} 52^{\prime} \mathrm{E}$ and $9^{\circ} 20^{\prime} \mathrm{E}$. The soil is predominantly ferruginous tropical red and brown soil common in the areas underlain by the Basement Complex rocks. Over large areas, the vegetation does not provide adequate cover for the soils especially at the beginning of the rains; hence the soils are generally susceptible to erosion. The climate is hot and dry for most of the year. Maximum day temperature of about $38^{\circ} \mathrm{C}$ in the months of March, April and May are common and the minimum temperature is about $22^{\circ} \mathrm{C}$ in the month of December and January. The mean annual rainfall is $780 \mathrm{~mm}$.

The area lies within the Sudan Savanna zone but its vegetation has been to a large extent modified as a result of several centuries of bush clearing for construction activities, bush burning, cultivation, animal grazing as well as fuel wood exploitation. In the closely settled area especially around Katsina town, natural vegetation is almost absent but several trees have been planted such as Azadiracta indica and Acacia albida. A considerable growth of natural vegetation occurs in areas that are marginal and not cultivated. The vast majority of migrants to Katsina Metropolis originate from rural areas where they have traditionally supported themselves through agriculture. Given their ability in this field, it is no surprise that they continue with such activities once they arrived at the city.

\section{MATERIALS AND METHODS}

Following a reconnaissance survey conducted across the entire Katina urban area (Fig. 1), UPA practices were identified to comprise three main farming systems: household or home gardening (mainly irrigated) taking place within and around homes; open or vacant-space cultivation (mainly rainfed) done in open spaces, undeveloped private, community and residential plots and peri-urban cultivation (both rainfed and irrigated) taking place on lands just outside the built area of the city. Of these systems, urban irrigation farming irrigated involves the use of wastewater that flows freely along the courses of Rivers Ginzo $\left(6.4 \mathrm{~km}^{2}\right.$ total drainage area with a length of $48 \mathrm{~km})$ and Talle $\left(12.2 \mathrm{~km}^{2}\right.$ with a length of about $26 \mathrm{~km}$ ), (Fig. 1). The two rivers collect water from several drains that run from the heart of Katsina Township towards the per-urban locations. Consequently, this study was deliberately focussed on the peri-urban locations where wastewater is reused in farming. It was also observed that the cultivated plots are owned on household basis, with members of a household performing various roles in the farming cycle adult males till the land, male children assist the adult males in planting, weeding and watering, conveyance the crops from the farms and subsequent marketing of the produce.

A total of 130 willing households were conveniently selected and interviewed out of the total number of 276 that officially registered with the Katsina Urban Planning Authority. The interview was with participants encountered on their farms.

To supplement the interview efforts, the researchers also observed, discuss with, and conducted focus-group interviews with the farmers. These discussions provided the opportunity for participants to share their feelings, insights and experiences about their needs and problems. The type of data sought from the interviews included the socio-economic and demographic characteristics of cultivators, farming practices, land ownership, motives for cultivation, problems they face as farmers in the urban area, source of water for their farming, reason for using it, consequences of using it, and awareness of those consequences. The responses received were summarised using simple descriptive statistics (percentage).

\section{RESULTS AND DISCUSSION \\ Gender Identity of the Cultivators}

Heads of all the studied households are males and they act as the custodians of the lands on behalf of the households. In other cities of Africa, males were found to dominate but not the sole owners of urban cultivated lands (Amar-Klemesu and Maxwell, 1998; Cencosad, 1994; Asomani-Boateng, 2002). In some urban area, women were found to predominate the urban farming population (Tripp, 1990 and Mvena et al. 1991, in Tanzania); (Sanyal, 1984, in Kenya, Uganda and Zambia). Informal discussions with some male farmers and female traders revealed that religious and cultural considerations which discourage women's active business activities in public (like in farming) were the main reasons for the male dominance of urban farming in the area. However, there are certain businesses in Katsina markets that are dominated by women and these include sales of farm produce and agro-based processed food items. Hence, the male farmers deliberately exclude the females from the farming activities and confine them instead to petty business of produce marketing. In Ghana, one urban cultivator was quoted by AsomaniBoateng (2002) as saying "I cannot compete with the women in selling foodstuffs, fish, meat and vegetables on the street, and even if I can, I will not feel comfortable in their midst". The reality is that throughout much of northern Nigeria where Islamic religion has a very strong influence, women do not farm by themselves but assist their husbands; therefore, it is quite uncommon for a woman to farm by herself. 


\section{Socio-Cultural Background of the Farmers}

All the studied farmers are Hausas (the main tribe in Katsina) and are Muslims (the main religion). Only about $30 \%$ of them are immigrants who moved from other towns and villages within Katsina state to reside in Katsina urban area. But none of these migrants claimed to have moved to the town with the sole objective of participating in urban farming. Instead, they claimed to have migrated to the town in search of typical opportunities a city offers (especially employment in formal and service sectors) but ventured into urban farming either due to hardships or as last resorts.

Only about $15 \%$ of the interviewed famers had any form of formal education and four out of them were found to be clerical staff of some government establishments who moved to the town to work as civil servants but ended up venturing into urban farming to supplement the meagre earning from their clerical jobs.

About two-thirds (65\%) of the farmers have engaged in urban agriculture from less than one-third $(30 \%)$ of them. For over two decades most of the farmers $(87 \%)$ declared urban cultivation to be their full time job and their main source of a livelihood. The remaining $13 \%$ indicated that they are engaged in other activities like trading, service (mechanics, electricians etc) and civil service jobs are supplemental occupational activities. In part because the job market in the formal sector has deteriorated none of the participants is contemplaty quitting urban agriculture. Indeed they stated that even if the job market is good they will not quit entirely but will cultivate on part-time basis. Others stated that because food cultivation supplements their income and household food purchases, they do not intend to quit now or in the near future.

Table 1: Age of the farmers Interviewed

\begin{tabular}{lll}
\hline Age & No. of Farmers & Percentage \% \\
$20-30$ & 6 & 4.62 \\
$31-40$ & 86 & 66.15 \\
41 above & 38 & 29.23 \\
Total & $\mathbf{1 3 0}$ & $\mathbf{1 0 0 . 0 0}$
\end{tabular}

\section{Land access, ownership and site selection}

Most (96\%) of the farmers own the land on which they cultivated and the land belongs to their entire household. Upon death, the ownership is transferred to the most senior of the male children who farms it on behalf of all the remaining members of the household. When crops are produced they are sold and the proceeds used to maintain the entire household. The average land ownership is 0.76 ha per household. Choice of a particular piece of land to cultivate is the proximity to residence $(3 \%)$, proximity to water and access to rent free-land (94\%), fertility and the suitability of the land for cultivation (3\%). Availability of water determines is the most important factor that determines whether the farmer cultivates seasonally or year round. This explains why vegetable growers, who need a lot of water for their operations, are mostly located near streams and drainage channels. Cultivating near streams and drainage channels makes it easier for the farmer to obtain much needed water for irrigation. None of the farmers indicated suffering from crop loses as a result of floods destroying his crops during the rainy season.

\section{Crops cultivated}

Nearly all the farmers (98\%) in the area cultivate mainly vegetables and only $2 \%$ cultivate cereals like maize and guinea corn. Vegetables grown were mainly exotics such as lettuce, onion, potato, sweet potato, cabbage, carrots, sweet peppers and peppers. Indigenous vegetables grown included okra, peppers, tomatoes, spinach and garden egg. These are not grown purposely for sale but rather are staples for the gardeners, and cultivated for personal consumption, although any surplus is sold. Fruits like pineapples, banana, guava, cashew, mangoes, paw paw, orange, are grown only in few locations mostly for personal consumption. Two types of cultivation were identified, determined by the availability of water: seasonal and year-round. Farmers who farm throughout the year cultivated mainly vegetables, which can be grown even in the absence of rain, provided there is water. However, farmers scheduled production to coincide with periods of high demand, although they nevertheless cultivate vegetables as many times of the year as they can, depending on the period of maturity of the vegetable crop, the ability to replenish the soil and, above all, the farmers' energy.

\section{Soil Fertility Maintenance}

Only $46(35 \%)$ of the farmers relied entirely on chemical fertiliser in soil fertility maintenance. On the other hand, about $65 \%$ make use of chemical fertiliser (NPK, Ammonium Sulphate and Urea), urban waste ash, household manure, poultry manure and animal dung in soil fertility maintenance. Reasons given by the farmers for these approaches are (i) chemical fertilisers are costly and largely unavailable, and (ii) because of close proximity to homes, wastes and manures can easily be moved to the farmlands and used. On the Jos plateau of Central Nigeria, urban irrigation farmers were also reported to be adopting this approach and by so doing are helping in disposal of the huge wastes that pile up in the town (Pasquini, 2006). It was also observed that cultivators treated some of the urban wastes before using them on their farms. Treatment techniques included mixing chicken droppings with sawdust, allowing it to dry, and then spreading it on beds to be planted. Others cocompost cow manure with crop residues, leaves and shrubs and kitchen waste on site and use the compost on their farms. 


\section{Returns on cultivation}

None of the household cultivators indicated cultivating crops purposely for home consumption. Though none could give precise figure of how much is earned per year on crop sales as their produce are never sold at once, figures ranging between 64,000 Nigerian Naira (about 400 US Dollars) and 350,000 Nigerian Naira (about 2,000 US Dollars) were speculated. When one considers that Nigeria is categorised among the low income countries one could say that the farmers are not in essence resource poor at least by Nigerian standard. In essence while urban farming with urban wastewater is contributing only a small proportion of national food supplier (Ellis and Sumbery, 1998), it is important within urban area, particularly as it serves as a major source of income for the urban poor; source of vegetables crops for urban dwellers; and creator and user of city organic waste, both plant and animals.

\section{Problems of urban cultivators}

Like urban farmers everywhere in Africa, cultivators in the study area encounter a number of problems in their farming operations. Finding land was the most common problem mentioned by farmers as they all rely on narrow stretches of land along the Tille and Ginzo rivers with very little or even no chance of expansion. Farmers complained that it is very expensive to farm in the city due to the high cost of farm inputs. Agrochemicals like fertilizers, pesticides, and insecticides are expensive. Consequently, some farmers have resorted to using cheap and banned alternatives like DDT. Some farmers, especially vegetable cultivators are using cow and chicken manure and compost, as alternative to chemical fertilizers because they are cheaper.

Farmers also complain of theft of their produce before harvest. To guard against theft, farmers have formed watch groups made up largely of their male children that take turns to guard their farms against theft, especially during harvesting periods. Some farmers have constructed sheds in which they stay to guard their farms at night.

Farmers had negative opinions about extension personnel and of the services provided by them. Extension officers were seen as very unreliable are not available when needed, and when available concentrate on only a few farmers. They are also known to be very unfriendly and rude towards farmers. Those who are unable to access the services of extension officers and tap their expertise, particularly in the application of agrochemicals, are forced to use their own instincts. Ultimately, farmers are applying these chemicals without any technical advice, with its negative consequence for the environment and for the health of farmers and consumers of farm produce. Since most of these farms are located near streams and creeks, the likelihood of pollution of these water bodies from these chemicals is very high.

The marketing of farm produce was reported as a major problem facing farmers, especially vegetable cultivators in the city. There is profound fluctuation in prices resulting from supply and demand, and the farmers have to sell their crops through middlemen and women. Usually, the middlemen who buy the most of the produce offer ridiculously low farm gate prices, which are not commensurate with the effort of the farmers and, since they have no alternative, must reluctantly accept the low prices. Furthermore, by insisting on buying whole beds of vegetables, the middlemen and women deny the farmers use of the beds until the crops are harvested.

Institutional arrangements for urban farming have not yet been put in place in the study area and as such the farmers did not complain of any official harassment. Many other research workers such as; Mbiba and Veenhuizen (2001), Ellis and Sumberg (1998) have shown that the use of urban space for agriculture has received little attention from policy makers, who often see it in rather negative light. But the UPA is greater in many countries than is formally acknowledge and is increasing, for example average farmed in Zimbabwean Capital, Harare (Africa) doubled between 1990 and 1994 (Mbiba, 1995). Even in the USA the extent of urban farming is greater than often thought.

\section{Challenges for Urban Landuse Planning}

The Katsina state government is currently making efforts to review the Katsina Urban Master Plan. Thus, a critical issue here is to what extent urban land use planning and urban agriculture will be mainstreamed in the new plan. Urban land use planning and urban agriculture seem to be in conflict. The first masterplan of the city (produced in the 1980s) generally failed to accommodate urban farming. Katsina is an urban area in crisis when it comes to land use planning, primarily due to the flouting of planning regulations. Residential development is taking place in environmentally sensitive areas (wetlands, floodplains, etc.), on proposed roads, and in waste dumps. In peri-urban areas of the city the situation is alarming. The rate at which agricultural land within this zone is being converted to residential use is high.

The mere presence of urban gardens in traditional African cities disqualified them from being classified as urban by colonial administrators. Morgan (1954) remarks about pre-colonial Igbo cities in Nigeria attest to this belief: the dispersed gardens and settlements of primitive cultivators are not concomitant with the rise of cities or the establishment of a stable administration over a large area... the arts and crafts associated with towns are simply not there in Ibo society. There is no doubt that definitions of urban and urban activities have most of the time excluded agricultural land use and agricultural activities. Having said this, why have contemporary urban planners in Africa, who know quite well that urban agriculture was recognized as a major land use by precolonial indigenous planners, and accommodated in their urban land use plans, failed to come to terms with such a stark reality? If planning is designed to better the lot of humankind, and if it is a dynamic activity which responds to the needs of society, and desirous of enhancing the liveability of human settlements, then within the context of the urban planning, one can safely conclude that African planners have failed to pursue these objectives by not accommodating, adopting, adapting and integrating what a significant number of urban residents in African cities have relied upon and continue to rely on, into the urban spatial system. The need to revolutionalize urban land use planning in African cities, to accommodate urban agriculture is paramount. Urban agriculture has urban planning implications in that land use planning decisions are about the type, amount, and location of land. Simply put it is about "what", "how much" and "where". 
Bajopas Volume 2 Number 2 December, 2009

It is a question of site and size. Questions urban planners always have to deal with in designating urban land uses are "is this use appropriate on this site", "where is this use most suitably located", "Are the uses located on the same site or adjacent sites compatible with one another", and "how much land is needed for a particular use". In promoting urban agricultural activities whether livestock, poultry, fish farming or cultivation of crops, one has to deal with above planning issues of "what" "how much" and "where".

\section{CONCLUSION}

Reuse of wastewater in urban farming in Katsina urban area is practiced not only as a fulltime and sole income earner for many households, but an activity that the town cannot do without. Being a city located within a semi-arid setting, relying on rainfall for successful promotion of urban farming is certainly a risky enterprise. Thus, resort to the reuse of wastewater that freely flows in drains within the urban and peri urban setting of the town is one of the readily available options. Unfortunately urban planning process has not officially

\section{REFERENCES}

Amar-Klemesu,M., \& Maxwell, D. (1998). Urban agriculture in the Greater Accra Metropolitan Area. Nutrition Unit Noguchi Memorial Institute for Medical Research,University of Ghana,Accra, Ghana.

Asomani-Boateng,R. (2002). Urban cultivation in Accra: an examination of the nature, practices, problems, potentials and urban planning implications. Habitat International 26 (2002) 591-607

Blumenthal, U., Peasey, A., Ruiz-Palacios, G., and Mara, D. D. (2000). Guidelines for wastewater reuse in agriculture and aquaculture: recommended revisions based on new research evidence. Task No. 68, Part 1. Retrieved from persistent URL: http://www.lboro.ac.uk/well/resources/well-studies/fullreports-pdf.

Cencosad (1994). Urban market gardens in Accra. Centre for Community Studies,Action and Development and the Mega Cities Project. Accra,Ghana.

Ellis, F., Sumberg, J. (1998): Food Production; Urban areas and policy responses. World Dev., 26(2), 213 - 225.

Ensink, J. H., van der Hoek, W., Matsuno, Y., Munir, S., and Aslam, M. R. (2002). Use of untreated wastewater in periurban agriculture in Pakistan: Risks and Opportunities. Research report 64, Colombo: International Water Management Institute (IWMI).

FAO (1999). Urban and Peri-Urban Agriculture. Report to the Fao Committee on Agriculture (Coag) Meeting from January 25-26. FAO, Rome.

Feigin, A., Ravina, I., and Shalhevet, J. (1991). Irrigation with treated sewage effluent. Berlin: Springer.

Horswell, J., Speir, T. W., and van Schaik, A. P. (2003). Bioindicators to assess impacts of heavy metals in the land applied sewage sludge. Soil Biology and Biochemistry, 35, 1501-1505.

Hussain, I., Raschid, L., Hanjra, M. A., Marikar, F., and Van der Hoek, W. (2001). A framework for analyzing socioeconomic, health and environmental impacts of wastewater use in agriculture in developing countries. Working Paper 26. Colombo: International Water Management Institute (IWMI)

Liu,W. H., Zhao, J. Z.,Ouyang, Z.Y., Solderland, L., and Liu,G. $\mathrm{H}$. (2005b). Impacts of sewage irrigation on heavy metal distribution and contamination in Beijing, China. Environmental International, 32, 805-812.

Lock K, van Veenhuizen R. (2001). Balancing the positive and negative health impacts. Urban Agric Mag 2001;3:1- 5 . recognised and given attention to this important activity. Urban farming should not be viewed as a subsidiary and blighted activity on the urban landscape but rather as an important strategy for developing more productive, viable and sustainable urban habitats. Emphasis should move from mere tolerance on the part of city administrators to one of officially sanctioned and promoted urban agriculture. This will require promoting urban agriculture within the framework of the country's agricultural and urban development policies, in which emphasis will be placed on incorporating urban agriculture into city plans. Planners should recognize the fact that agriculture is as valuable in the use of urban land as industry, housing and commerce, and should, therefore, prepare land use plans and regulations, which accommodate agriculture. It will also require, among other things, addressing the issue of loan, marketing, and inputs like seedlings and training the urban farmers which are major problems facing urban farmers in Katsina and in most African cities.

Lynch K., Binns T. and Olofin E. A. (2001). Urban agriculture under threat: the land security question in Kano, Nigeria. Cities 18:159- 71

Mbiba, B. (1995): Urban Agriculture in Zimbabwe. Aldershot, England: Avery Ashgate Publishing Limited.

Mbiba B, Van Veenhuizen R. (2001).The integration of urban and periurban agriculture into planning. Urban Agric Magazine 4:1- 6.

Morgan,W. B. (1954). Approaches to regional studies in Nigeria. Research Notes, 6(2), 10-18.

Mvena,Z. S. K.,Lupanga,I. J.,Mlozi,M. R. S. (1991). Urban agriculture in Tanzania: A study of six towns. Draft Report,IDRC (Project 86-0090),Ottawa,Canada.

Pasquini, W.M. (2006).The use of town refuse ash in urban agriculture around Jos, Nigeria: health and environmental risks. Science of the Total Environment 354 (2006) 43- 59.

Sanyal,B. (1984). Urban agriculture: A strategy of survival in Zambia. Ph.D. Thesis,School of Planning, University of California, Los Angeles, USA.

Scott, C. A; Zarazu'a J. A; Levine, G. (2004): Urban wastewater reuse for crop production in the water-short Guanajuato river basin. Mexico. Research report No. 41.34 p. ISBN 92-9090-404-6.

Sharma, R. K., Agrawal, M., and Marshall, F. (2007). Heavy metal contamination of soil and vegetables in suburban areas of Varansi, India. Ecotoxicology and Environmental Safety, 66, 258-266.

Sweet L. (1999). Room to live-healthy cities for the urban century. IDRC briefing. Ottawa, Canada7 IDRC.

Tripp,A. M. (1990). The urban informal economy and the state in Tanzania. Ph.D. Thesis, Northwestern University, Evanston,IL,USA.

Urie, D. H. (1986). The status of wastewater irrigation of forest. In D. W. Cole, C. L. Henry, and W. L. Nutter (Eds.), The forest alternative for treatment and utilization of municipal and industrial wastes. Seattle: University of Washington Press.

UNDP (1996): Urban agriculture; Food, Jobs and sustainable cities. New York UNDP.

World Health Organization (WHO) (2006). Guidelines for the safe use of wastewater, excreta and greywater: Wastewater use in agriculture (Volume II). Retrieved from persistentURL: http://www.who.int/water sanitation health/wastewate r/gsuweg2/en/index.html. 